\title{
Fitzner/ Eberhardt Arid Lands Ecology (ALE) Reserve Soil Sampling and Analysis Plan
}

B. G. Fritz

T. M. Poston

R. L. Dirkes

April 2004

Prepared for the U.S. Department of Energy under Contract DE-AC06-76RL01830 


\title{
DISCLAIMER
}

This report was prepared as an account of work sponsored by an agency of the United States Government. Neither the United States Government nor any agency thereof, nor Battelle Memorial Institute, nor any of their employees, makes any warranty, express or implied, or assumes any legal liability or responsibility for the accuracy, completeness, or usefulness of any information, apparatus, product, or process disclosed, or represents that its use would not infringe privately owned rights. Reference herein to any specific commercial product, process, or service by trade name, trademark, manufacturer, or otherwise does not necessarily constitute or imply its endorsement, recommendation, or favoring by the United States Government or any agency thereof, or Battelle Memorial Institute. The views and opinions of authors expressed herein do not necessarily state or reflect those of the United States Government or any agency thereof.

\author{
PACIFIC NORTHWEST NATIONAL LABORATORY \\ operated by \\ BATTELLE \\ for the
UNITED STATES DEPARTMENT OF ENERGY under Contract DE-AC06-76RL01830

Printed in the United States of America
Available to DOE and DOE contractors from the Office of Scientific and Technical Information, P.O. Box 62, Oak Ridge, TN 37831-0062; ph: (865) 576-8401 fax: (865) 576-5728
email: reports@adonis.osti.gov

\author{
Available to the public from the National Technical Information Service, \\ U.S. Department of Commerce, 5285 Port Royal Rd., Springfield, VA 22161 \\ ph: (800) 553-6847 \\ fax: (703) 605-6900 \\ email: orders@ntis.fedworld.gov \\ online ordering: http://www.ntis.gov/ordering.htm
}




\title{
Fitzner/Eberhardt Arid Lands Ecology (ALE) Reserve Soil Sampling and Analysis Plan
}

\author{
B. G. Fritz \\ T. M. Poston \\ R. L. Dirkes
}

April 2004

Prepared for the U.S. Department of Energy under Contract DE-AC06-76RL01830

Pacific Northwest National Laboratory Richland, Washington 99352 


\section{Summary}

The U.S. Department of Energy (DOE) plans to transfer the Fitzner/Eberhardt Arid Lands Ecology (ALE) Reserve to the U.S. Department of the Interior (DOI) as part of its efforts to reduce the size of the Hanford Site. Before transfer of this approximately 311- $\mathrm{km}^{2}$ parcel can be achieved, DOE must evaluate the potential for residual radioactive contamination of this land and determine compliance with DOE Order 5400.5. As part of this process, radiological release criteria (Authorized Limits) were developed by the DOE Richland Operations Office (DOE-RL) and approved by DOE Headquarters' Office of Environmental Management (DOE-EM).

To assist DOE with the land transfer process, Pacific Northwest National Laboratory (PNNL) developed this soil sampling and analysis plan, which describes sampling and analysis that will be conducted on ALE to demonstrate compliance with the DOE-EM approved Authorized Limits. Results of this analysis will be described in a follow-up report. 


\section{Contents}

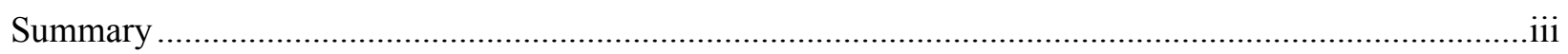

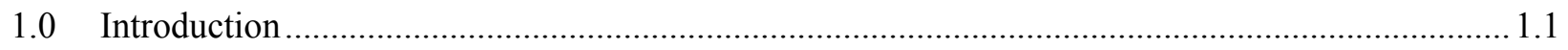

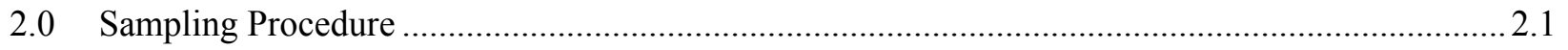

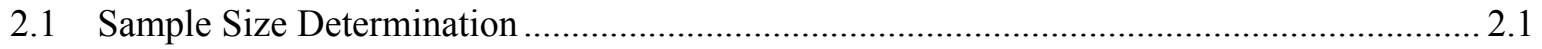

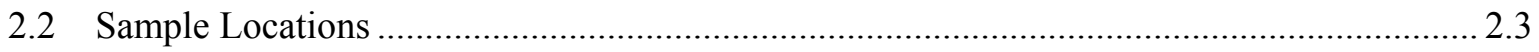

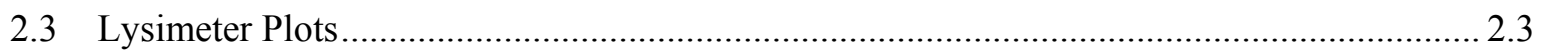

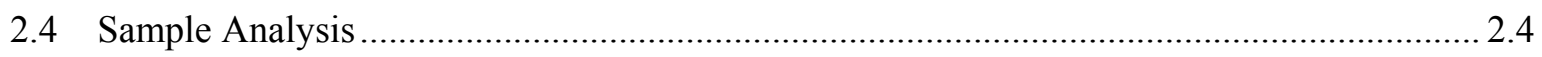

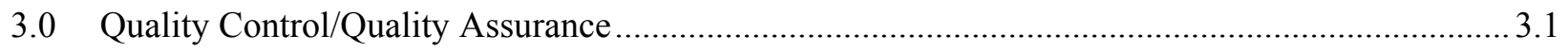

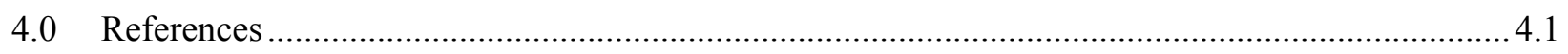

Appendix A - Systematic Sampling Locations for Comparing a Median with a Fixed Threshold..........A.1 


\section{Figures}

1.1 Hanford Reach National Monument Units with Central Plateau Wind Rose................................ 1.1

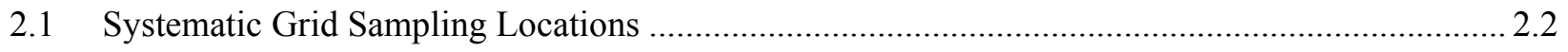

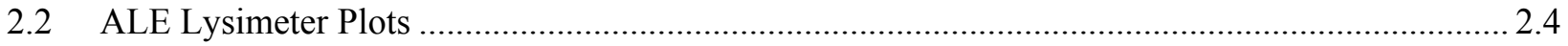

\section{Tables}

2.1 Locations of Soil Sampling Sites and Number of Samples Planned for Collection from ALE.......2.2

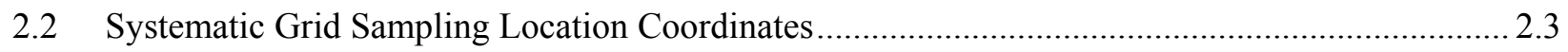

2.3 Analytes, Detection Limits and Authorized Limits for the ALE Unit....................................... 2.5 


\subsection{Introduction}

The Hanford Reach National Monument (HRNM) consists of several units, one of which is the Fitzner-Eberhardt Arid Lands Ecology (ALE) Reserve. This unit is approximately 311 square kilometers of shrub-steppe habitat located south and west of Highway 240 (Figure 1.1). To support a transfer of this land, the U.S. Department of Energy (DOE) must evaluate the potential for residual radioactive contamination on this land, and determine compliance with the requirements of DOE Order 5400.5 (DOE 1993). This process includes developing a historical site assessment that summarizes the activities conducted on ALE, discusses potential sources of radiological contaminants that may be present on ALE,

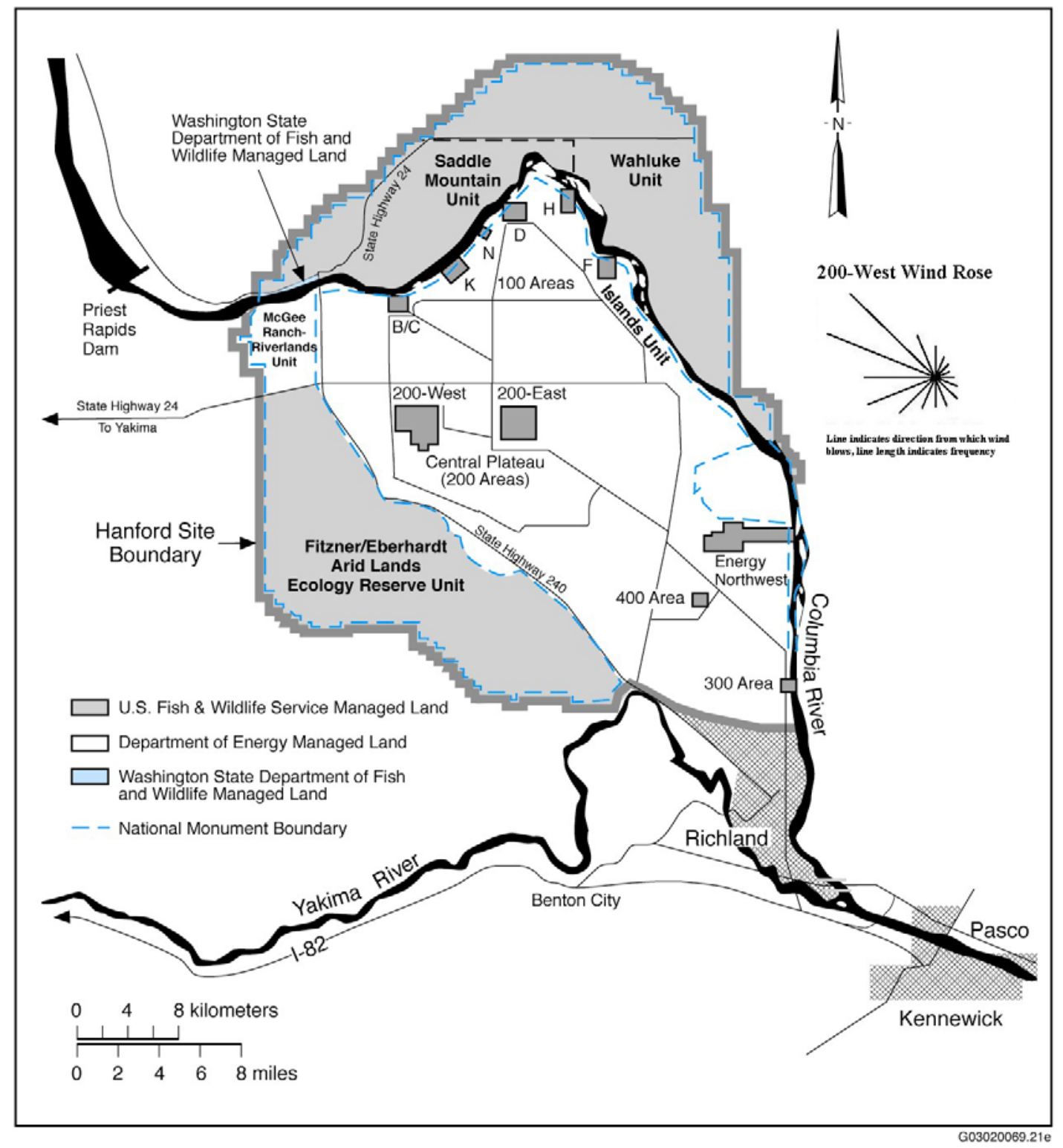

Figure 1.1. Hanford Reach National Monument Units with Central Plateau Wind Rose 
and summarizes environmental and ecological information from past studies that may be useful in characterizing the levels of radionuclides present on the unit.

DOE Order 5400.5 also requires that a request for radiological release criteria, i.e., Authorized Limits, be developed and submitted to the applicable DOE headquarters program office for approval. For the Hanford Site, this is the DOE Office of Environmental Management (DOE-EM). This request, which is based on an annual exposure limit of $100 \mathrm{mrem}$ to the public using future potential land use scenarios, was submitted to DOE-EM on December 22, 2003. DOE-EM approved the requested Authorized Limits on March 1, 2004.

This document describes soil sampling and analysis that will be conducted on ALE to characterize the concentrations of radionuclides present in soil and demonstrate compliance with the Authorized Limits. Samples will be collected from pre-determined locations on the ALE unit and analyzed for a suite of radioactive constituents. The results of these soil samples will be evaluated to determine if the ALE unit has concentrations of radionuclides that are below the approved Authorized Limits.

The only known activities conducted on ALE that could have resulted in radionuclides being released on ALE were research activities (Fritz et al. 2003; O'Connor and Rickard 2003). Some ecological studies conducted on ALE used radioisotopes as tracers, but no other known Hanford operations occurred on ALE that used or could have resulted in release of radionuclides to the ALE environment (Fritz et al. 2003). The main source of radionuclides present in ALE soil is atmospheric deposition from worldwide fallout and Hanford atmospheric emissions in the 200 Areas (Fritz et al. 2003). The wind across the Hanford Site is generally from the northwest to the southeast (see Figure 1.1), so atmospheric deposition onto ALE is likely to have resulted in the highest soil concentrations in the southeast portion of ALE. For most radionuclides, vertical migration through the soil is limited (Fritz et al. 2003), so sampling the surface soil provides the best estimation of accumulated radionuclide concentrations, and therefore, the best data for determining if ALE complies with the approved Authorized Limits. The goal and design criteria of this sampling effort is to collect an adequate number of soil samples to determine if the concentrations of radionuclides of concern in ALE soil are below the approved Authorized Limits with a high degree of statistical confidence (99\%). 


\subsection{Sampling Procedure}

Pacific Northwest National Laboratory's (PNNL) Surface Environmental Surveillance Project (SESP) staff will be responsible for sample collection. Sample collection will be conducted according to procedures established and used for the SESP (Hanf and Poston 2004). The soil collection procedure consists of collecting five separate samples of the surface soil and compositing them into a single sample submitted for analysis. The procedure calls for collecting samples from areas that have a minimum amount of vegetative cover, do not appear to have been eroded recently, are not rocky, and are separated by at least 30 feet. Collection staff will record the latitude and longitude of each sampling location for accurate spatial analysis of the data. This procedure is the same one used in the collection of historical soil concentration data evaluated in the historical site assessment (Fritz et al. 2003). Using the same procedure allows for consistent collection techniques and comparable data. All sample collection documentation will be consistent with established SESP sample collection and chain-of-custody protocol.

\subsection{Sample Size Determination}

To determine the number of samples necessary to characterize the ALE unit, and provide a high degree statistical confidence that the Authorized Limits are not exceeded, the Visual Sample Plan (VSP) computer program was used (Gilbert et al. 2001; Hassig 2002). This program was developed to provide a tool for selecting the right number and location of environmental samples so that the results of statistical tests performed on data collected via the sampling and analysis plan have the required confidence for decision making. To determine the minimum number of samples necessary to determine ALE compliance with the approved Authorized Limits, the VSP program was run for all the radionuclides in the Authorized Limits. The radionuclide that requires the most sampling to determine compliance with the approved Authorized Limits is cesium-137. Analyzing historical data for the ALE unit (Fritz et al. 2003) and other historical soil monitoring data provided the data necessary to make assumptions that were required for the analysis, including assuming a standard deviation of $0.3 \mathrm{pCi} / \mathrm{g}$ (see Appendix A). To provide a high degree of confidence that ALE complies with the approved Authorized Limits, parameters were set in the VSP program to provide only a $1 \%$ chance of incorrectly concluding the site had concentrations below the approved Authorized Limits. The results of VSP indicated that, for the ALE unit, 31 soil samples are required. A detailed description of the VSP results for this sampling plan is included in Appendix A.

Although the VSP program is a useful tool in establishing the number of samples necessary for determining compliance with approved Authorized Limits, some design assumptions in the VSP program warrant further consideration in the development of the ALE soil sampling plan. The VSP program assumes the contaminants to be evenly distributed across the area of interest and the terrain to be flat. Neither of these assumptions is valid for ALE. Price and Dirkes (1981) observed plutonium-239/40 concentrations on the portion of ALE south and east of the 200 Areas that were higher by a statistically significant amount than concentrations measured on the portion of ALE west and south of the 200 Areas (Fritz et al. 2003). To account for this spatial distribution, ALE was split into two parts for the VSP program execution: West ALE and East ALE (Figure 2.1). To assure the sampling design allows for an evaluation of potential spatial differences, due to elevation or variability in concentrations across ALE, a random start grid pattern, rather than randomly selected individual sampling locations, was used in 


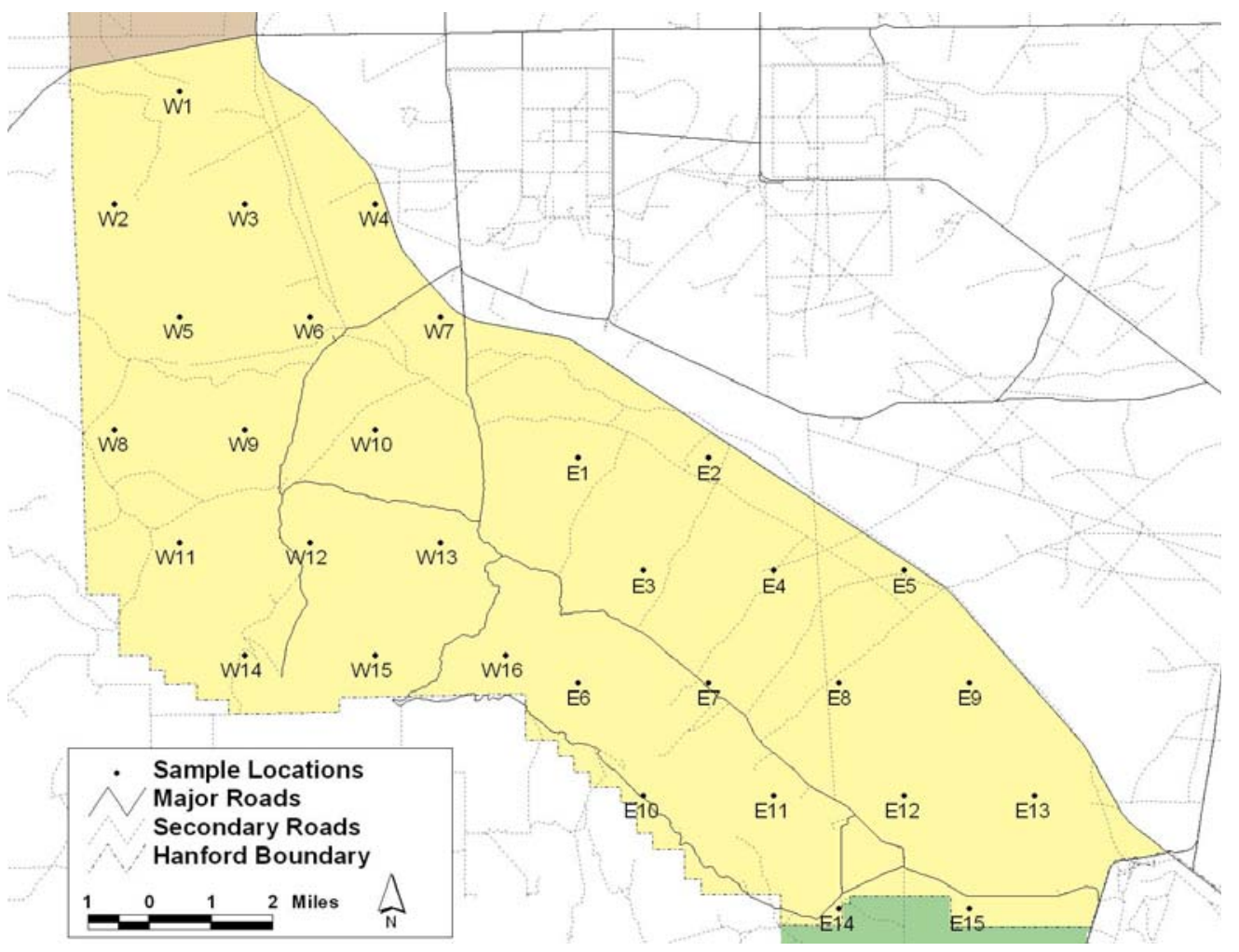

Figure 2.1. Systematic Grid Sampling Locations

selection of the sampling points. The random start grid pattern maintains the requirement for random sample locations and ensures that samples are collected from different elevations and evenly distributed locations across ALE. To further account for terrain and elevation effects, as well as potential radiological contaminant concentration variability on ALE, nine additional soil samples will be collected. These samples will be collected at locations with increased potential for accumulation of radiological contaminants either through atmospheric deposition or erosion and alluvial deposition.

Overall, 50 soil samples will be collected across the ALE site. The locations of soil sampling sites and number of samples planned for collection are outlined in Table 2.1. These 50 samples should provide a sufficient sample size to allow a statistically valid determination of whether the ALE site has concentrations of radionuclides in soil below the approved Authorized Limits.

Table 2.1. Locations of Soil Sampling Sites and Number of Samples Planned for Collection from ALE

\begin{tabular}{|l|c|}
\hline \multicolumn{1}{|c|}{ Sampling Site } & Number of Samples \\
\hline East ALE random start grid & 15 \\
\hline West ALE random start grid & 16 \\
\hline Additional ALE samples at selected locations & 9 \\
\hline Lower Snively lysimeter plot & 5 \\
\hline ALE Headquarters lysimeter plot & 5 \\
\hline TOTAL soil samples & 50 \\
\hline
\end{tabular}




\subsection{Sample Locations}

Using the VSP program with a systematic grid pattern and a random starting location, good spatial coverage of the ALE unit was achieved. Sampling locations calculated by VSP are illustrated in Figure 2.1, and Global Positioning System (GPS) coordinates are provided in Table 2.2. It is assumed that due to rugged terrain on parts of ALE, sampling exactly at the selected locations may not be possible at all locations. Every reasonable effort will be made by collection staff to collect samples from the predetermined locations, but for those locations deemed inaccessible, samples will be collected as close as possible to the location determined by the VSP program, and any deviation addressed in the data analysis. For the additional nine samples being collected to augment the sampling locations determined by VSP, samples will be collected from alluvial fans at the base of Rattlesnake Mountain, in drainage washes, or from areas that appear to have collected windblown sand.

\subsection{Lysimeter Plots}

On ALE, three lysimeter plots were identified as having used radionuclides for research (Figure 2.2; Fritz et al. 2003). One of these plots (K. Moss) used iodine-131 $\left(\mathrm{t}_{1 / 2}=8\right.$ days), while the other two lysimeter plots used isotopes with longer half-lives (plutonium-238, $\mathrm{t}_{1 / 2}=88$ years; plutonium-239, $\mathrm{t}_{1 / 2}=$ 24000 years; americium-241, $\mathrm{t}_{1 / 2}=430$ years; curium- $244, \mathrm{t}_{1 / 2}=18.1$ years; neptunium-237, $\mathrm{t}_{1 / 2}=$ 2140000 years). No samples will be collected from the K. Moss plot since any iodine-131 present would have decayed below detectable levels long ago. Five additional soil samples will be collected from the other two lysimeter plots (ALE Headquarters and Lower Snively). The sampling locations within the plots will be determined onsite by collection staff.

Table 2.2. Systematic Grid Sampling Location Coordinates

\begin{tabular}{|c|c|c|c|c|c|}
\hline \multicolumn{3}{|c|}{ West ALE } & \multicolumn{3}{c|}{ East ALE } \\
\hline Name & Longitude & Latitude & Name & Longitude & Latitude \\
\hline W1 & 119.75419 & 46.56426 & E1 & 119.62040 & 46.47749 \\
\hline W2 & 119.77666 & 46.53798 & E2 & 119.57624 & 46.47714 \\
\hline W3 & 119.73245 & 46.53769 & E3 & 119.59875 & 46.45090 \\
\hline W4 & 119.68824 & 46.53739 & E4 & 119.55461 & 46.45054 \\
\hline W5 & 119.75492 & 46.51142 & E5 & 119.51047 & 46.45017 \\
\hline W6 & 119.71073 & 46.51112 & E6 & 119.62125 & 46.42465 \\
\hline W7 & 119.66654 & 46.51081 & E7 & 119.57713 & 46.42430 \\
\hline W8 & 119.77736 & 46.48514 & E8 & 119.53301 & 46.42393 \\
\hline W9 & 119.73319 & 46.48485 & E9 & 119.48890 & 46.42355 \\
\hline W10 & 119.68902 & 46.48455 & E10 & 119.59963 & 46.39805 \\
\hline W11 & 119.75564 & 46.45858 & E11 & 119.55553 & 46.39770 \\
\hline W12 & 119.71149 & 46.45828 & E12 & 119.51143 & 46.39732 \\
\hline W13 & 119.66734 & 46.45797 & E13 & 119.46734 & 46.39693 \\
\hline W14 & 119.73394 & 46.43201 & E14 & 119.53395 & 46.37109 \\
\hline W15 & 119.68981 & 46.43170 & E15 & 119.48987 & 46.37071 \\
\hline W16 & 119.64569 & 46.43138 & & & \\
\hline
\end{tabular}




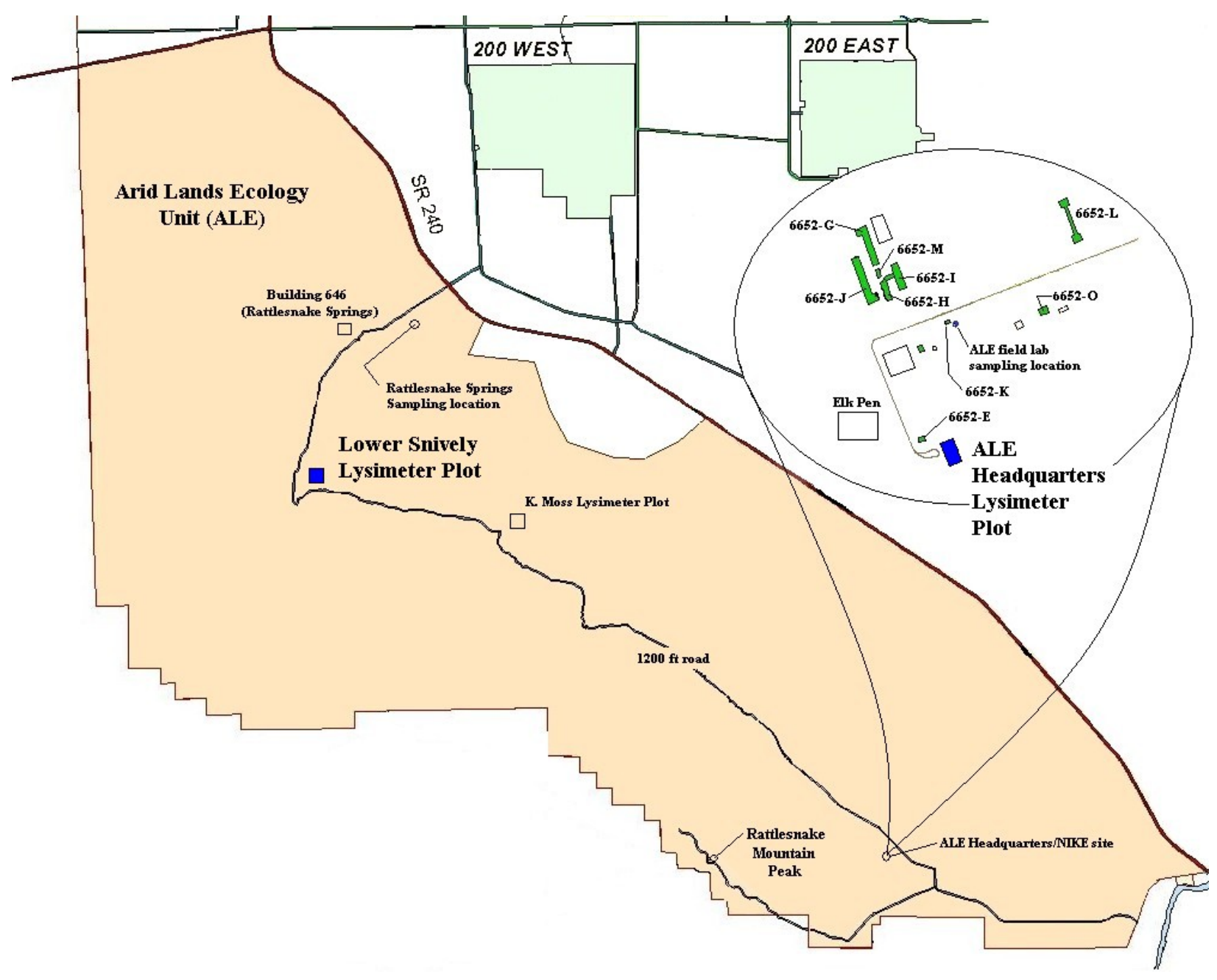

Figure 2.2. ALE Lysimeter Plots

\subsection{Sample Analysis}

A sub-contracted analytical laboratory will analyze soil samples collected by the SESP. This same laboratory analyzes routine soil samples collected by the SESP, which again provides consistency with historical data. The suite of radionuclides selected for analysis (Table 2.3) was determined from historical data and the derivation of the approved Authorized Limits (Fritz et al. 2003; Napier et al. 2004). The analytical methods used are adequate to detect concentrations well below the approved Authorized Limits. This list includes those radionuclides emitted in significant amounts to air from past Hanford operations. The only radionuclides that were used on the lysimeter plots, and therefore, could potentially be present in the soil, but for which analyses are not performed, are curium-244 and neptunium-237. If data from the lysimeter plots indicate levels of any radionuclides above the levels observed across the ALE unit, additional analyses for these constituents will be considered. 
Table 2.3. Analytes, Detection Limits and Authorized Limits for the ALE Unit

\begin{tabular}{|l|c|c|}
\hline \multicolumn{1}{|c|}{ Radionuclide } & Analytical Detection Limit (pCi/g) & Authorized Limit (pCi/g) \\
\hline Cobalt-60 & 1 & 11 \\
\hline Cesium-134 & 1 & 20 \\
\hline Cesium-137 & 1 & 46 \\
\hline Europium-152 & 1 & 24 \\
\hline Strontium-90 & 10 & 88 \\
\hline Uranium-234 & 100 & 2400 \\
\hline Uranium-235 & 10 & 190 \\
\hline Uranium-238 & 50 & 770 \\
\hline Plutonium-239/40 & 25 & 480 \\
\hline Americium-241 & 10 & 420 \\
\hline (a) For samples from lysimeter plots only. \\
\hline
\end{tabular}




\subsection{Quality Control/Quality Assurance}

Quality control and quality assurance will be maintained through protocols and procedures currently in place for the SESP. This includes collection procedures, records management, chain-of-custody protocol, database management, data verification, and analytical techniques. These are detailed in the SESP Quality Assurance Project Plan. A portion of all samples will be archived to allow for any future re-analysis or to analyze for other constituents that may be deemed necessary. 


\subsection{References}

Fritz BG, RL Dirkes, TM Poston, and RW Hanf. 2003. Historical Site Assessment: Hanford Reach National Monument -- Fitzner-Eberhardt Arid Lands Ecology Reserve (ALE), McGee Ranch, Riverlands, and Wahluke Slope. PNNL-13989, Pacific Northwest National Laboratory, Richland, Washington.

Gilbert RO, JR Davidson Jr., JE Wilson, BA Pulspher. 2001. Visual Sample Plan (VSP) Models and Code Verification. PNNL-13450, Pacific Northwest National Laboratory, Richland, Washington.

Hanf RW and TM Poston. 2004. Surface Environmental Surveillance Procedures Manual. PNL-MA580, Rev. 4. Pacific Northwest National Laboratory, Richland, Washington.

Hassig NL, RF O'Brien, JE Wilson, BA Pulsipher, RO Gilbert, CA McKinstry, DK Carlson, and DJ Bates. 2002. Visual Sample Plan 2.0 User's Guide. PNNL-14002, Pacific Northwest National Laboratory, Richland, Washington.

MARSSIM. 2000. Multi-agency Radiation Survey and Site Investigation Manual (MARSSIM) Rev. 1. NUREG-1575, Nuclear Regulatory Commission, Washington, DC. EPA 402-R-97-016, Environmental Protection Agency, Washington, DC.

Napier BA, WE Kennedy Jr., TA Ikenberry, MM Hunacek, AM Kennedy. 2004. Technical Basis for the Derivation of Authorized Limits for the Hanford Reach National Monument. Draft - in production, Pacific Northwest National Laboratory, Richland, Washington.

O'Connor GP and WH Rickard. 2003. A History of the Fitzner-Eberhardt Arid Lands Ecology Reserve: Four Decades of Environmental Research. PNNL-SA-39326, Pacific Northwest Laboratory, Richland, Washington.

Price KR and RL Dirkes. 1981. Plutonium in Surface Soil Near the Southwestern Boundary of the Hanford Project. PNL-3647, Pacific Northwest Laboratory, Richland, Washington.

U.S. Department of Energy (DOE). 1993. Radiation Protection of the Public and Environment. DOE Order 5400.5/Change 2. Washington, D.C.

U.S. Environmental Protection Agency (EPA). 2000. Guidance for the Data Quality Objectives (DQO) Process. EPA QA/G-4. EPA/600/R-96/055, EPA, Quality Staff, Washington, DC. 


\section{Appendix A}

Systematic Sampling Locations for Comparing a Median with a Fixed Threshold (Nonparametric - MARSSIM) 


\section{Appendix A}

\section{Systematic Sampling Locations for Comparing a Median with a Fixed Threshold (Nonparametric - MARSSIM)}

\section{A.1 Summary}

This appendix summarizes the sampling design used, associated statistical assumptions, as well as general guidelines for conducting post-sampling data analysis. Sampling plan components presented here include how many sampling locations to choose and where within the sampling area to collect those samples. The type of medium to sample (i.e., soil, groundwater, etc.) and how to analyze the samples (insitu, fixed laboratory, etc.) are addressed in other sections of the sampling and analysis plan.

The following table summarizes the sampling design used. A figure that shows sampling locations in the field and a table that lists sampling location coordinates are also provided.

\begin{tabular}{|c|c|}
\hline \multicolumn{2}{|c|}{ SUMMARY OF SAMPLING DESIGN } \\
\hline Primary Objective of Design & Compare site mean or median to Authorized Limits \\
\hline Type of Sampling Design & Nonparametric \\
\hline Sample Placement (Location) in the Field & Systematic with a random start location \\
\hline Working (Null) Hypothesis & The median (mean) value at the site exceeds the threshold \\
\hline $\begin{array}{l}\text { Formula for calculating number of sampling } \\
\text { locations }\end{array}$ & Sign Test - MARSSIM version \\
\hline Calculated total number of samples & 31 \\
\hline Number of samples on map & 31 \\
\hline Number of selected sample areas ${ }^{(a)}$ & 2 \\
\hline Sampling area ${ }^{(b)}$ & $3.088 \mathrm{e}+8 \mathrm{~m}^{2}$ \\
\hline Size of grid / Area of grid cell ${ }^{(\mathrm{c})}$ & $11126 \mathrm{ft} / 1.072 \mathrm{e}+8 \mathrm{ft}^{2}$ \\
\hline Grid pattern & Triangle \\
\hline $\begin{array}{l}\text { (a) Number of selected sample areas is the } n \\
\text { (b) Sampling area is the surface area of the } s \\
\text { (c) Size of grid / Area of grid cell gives the } 1 \\
\text { samples. }\end{array}$ & $\begin{array}{l}\text { f colored areas which contain sampling location on the map. } \\
\text { ample areas. } \\
\text { square dimensions of the grid used to systematically place }\end{array}$ \\
\hline
\end{tabular}




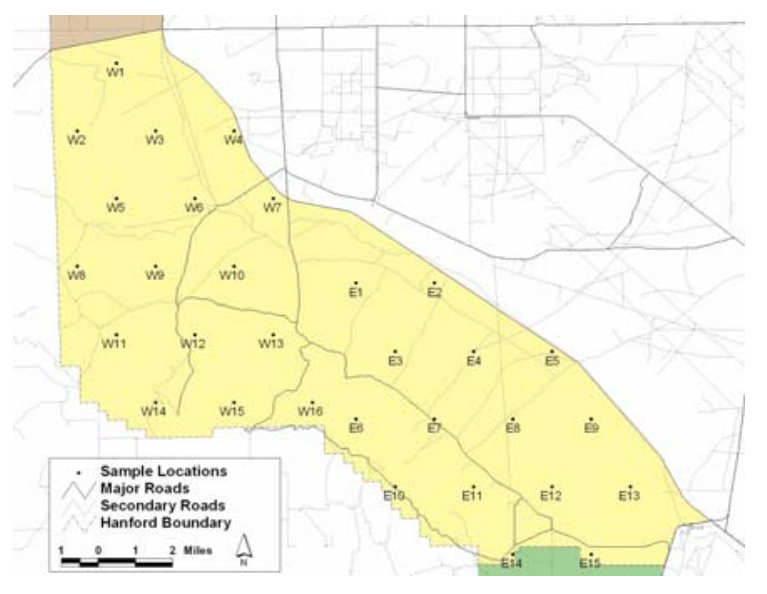

Area 1- West ALE

\begin{tabular}{|c|c|c|c|}
\hline X Coord & Y Coord & Longitude & Latitude \\
\hline 557177 & 137088 & 119.754191 & 46.564262 \\
\hline 555481 & 134151 & 119.776659 & 46.537983 \\
\hline 558873 & 134151 & 119.732448 & 46.537694 \\
\hline 562264 & 134151 & 119.688237 & 46.537389 \\
\hline 557177 & 131214 & 119.754915 & 46.511419 \\
\hline 560568 & 131214 & 119.710726 & 46.511123 \\
\hline 563960 & 131214 & 119.666537 & 46.510809 \\
\hline 555481 & 128277 & 119.777360 & 46.485140 \\
\hline 558873 & 128277 & 119.733192 & 46.484852 \\
\hline 562264 & 128277 & 119.689025 & 46.484547 \\
\hline 557177 & 125340 & 119.755637 & 46.458576 \\
\hline 560568 & 125340 & 119.711491 & 46.458280 \\
\hline 563960 & 125340 & 119.667345 & 46.457966 \\
\hline 558873 & 122403 & 119.733935 & 46.432009 \\
\hline 562264 & 122403 & 119.689810 & 46.431704 \\
\hline 565655 & 122403 & 119.645686 & 46.431382 \\
\hline
\end{tabular}

\section{Area 2- East ALE}

\begin{tabular}{|c|c|c|c|}
\hline X Coord & Y Coord & Longitude & Latitude \\
\hline 567541 & 127549 & 119.620396 & 46.477490 \\
\hline 570933 & 127549 & 119.576235 & 46.477141 \\
\hline 569237 & 124612 & 119.598753 & 46.450896 \\
\hline 572628 & 124612 & 119.554613 & 46.450539 \\
\hline 576020 & 124612 & 119.510475 & 46.450165 \\
\hline 567541 & 121675 & 119.621248 & 46.424647 \\
\hline 570933 & 121675 & 119.577130 & 46.424299 \\
\hline 574324 & 121675 & 119.533013 & 46.423933 \\
\hline 577715 & 121675 & 119.488895 & 46.423551 \\
\hline 569237 & 118738 & 119.599625 & 46.398054 \\
\hline 572628 & 118738 & 119.555528 & 46.397697 \\
\hline 576020 & 118738 & 119.511433 & 46.397323 \\
\hline 579411 & 118738 & 119.467337 & 46.396933 \\
\hline 574324 & 115801 & 119.533948 & 46.371091 \\
\hline 577715 & 115801 & 119.489874 & 46.370709 \\
\hline
\end{tabular}




\section{A.2 Primary Sampling Objective}

The primary purpose of sampling at this site is to compare a site median or mean value with a fixed threshold (i.e., Authorized Limits). The working hypothesis (or 'null' hypothesis) is that the median (mean) value at the site is equal to or exceeds the threshold. The alternative hypothesis is that the median (mean) value is less than the threshold. VSP calculates the number of samples required to reject the null hypothesis in favor of the alternative one, given a selected sampling approach and inputs to the associated equation.

\section{A.3 Selected Sampling Approach}

A nonparametric systematic sampling approach with a random start was used to determine the number of samples and to specify sampling locations. A nonparametric formula was chosen because the conceptual model and historical information (e.g., historical data from this site or a very similar site) indicate that typical parametric assumptions may not be true.

Both parametric and non-parametric equations rely on assumptions about the population. Typically, however, non-parametric equations require fewer assumptions and allow for more uncertainty about the statistical distribution of values at the site. The trade-off is that if the parametric assumptions are valid, the required number of samples is usually less than if a non-parametric equation was used.

Locating the sample points over a systematic grid with a random start ensures spatial coverage of the site. Statistical analyses of systematically collected data are valid if a random start to the grid is used. One disadvantage of systematically collected samples is that spatial variability or patterns may not be discovered if the grid spacing is large relative to the spatial patterns.

\section{A.4 Number of Total Samples: Calculation Equation and Inputs}

The equation used to calculate the number of samples is based on a Sign test (see PNNL 13450 for discussion). For this site, the null hypothesis is rejected in favor of the alternative one if the median (mean) is sufficiently smaller than the threshold. The number of samples to collect is calculated so that if the inputs to the equation are true, the calculated number of samples will cause the null hypothesis to be rejected.

The formula used to calculate the number of samples is:

$$
n=1.20\left[\frac{\left(Z_{1-\alpha x}+Z_{1-\beta}\right)^{2}}{4(\operatorname{Sign} P-0.5)^{2}}\right]
$$

where 


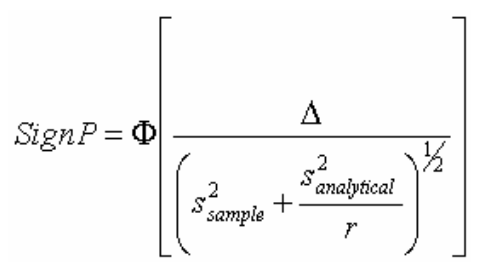

$\Phi(\mathrm{z})$ is the cumulative standard normal distribution on $(-\infty, \mathrm{z})$ (see PNNL-13450 for details),

$n \quad$ is the number of samples,

$S \quad$ is the estimated standard deviation of the measured values including analytical error,

$\Delta \quad$ is the width of the gray region,

$\alpha \quad$ is the acceptable probability of incorrectly concluding the site median (mean) is less than the threshold,

$\beta \quad$ is the acceptable probability of incorrectly concluding the site median (mean) exceeds the threshold,

$Z_{1-\alpha} \quad$ is the value of the standard normal distribution such that the proportion of the distribution less than $Z_{1-\alpha}$ is $1-\alpha$,

$Z_{1-\beta} \quad$ is the value of the standard normal distribution such that the proportion of the distribution less than $Z_{1-\beta}$ is $1-\beta$.

Note: MARSSIM suggests that the number of samples should be increased by at least $20 \%$ to account for missing or unusable data and uncertainty in the calculated value of $\mathrm{n}$. VSP allows a user-supplied percent overage as discussed in MARSSIM (2000).

The values of these inputs that result in the calculated number of sampling locations were selected based on expected conditions on the ALE site and the desired confidence in the end result. $\mathrm{S}$ is the standard deviation in the results including analytical error. This value was determined based on historical soil samples collected on and near the ALE site. The gray region $(\Delta)$ was selected to be equal to the standard deviation. The acceptance threshold for incorrectly concluding the site median is less than the Authorized Limits $(\alpha)$ was set at $1 \%$. This provides a $99 \%$ confidence in the result if the ALE site is determined to be below the Authorized Limits. If the ALE site is determined to be above the Authorized Limits, there will be a $90 \%$ confidence in that result, since a beta $(\beta)$ of $10 \%$ was chosen. It was decided that if the results indicated that the ALE site exceeded Authorized Limits, more sampling could be done to confirm that result, so a higher chance of incorrectly determining the site exceed the Authorized Limits was acceptable. A 10\% MARSSIM overage was selected to account for any missing or unusable data. A $10 \%$ addition was considered acceptable since an additional 9 soil samples will be collected in addition to the samples identified in this statistical evaluation. 


\begin{tabular}{|c|c|}
\hline Parameter & Value \\
\hline$S$ & 0.3 \\
\hline$\Delta$ & 0.3 \\
\hline$\alpha$ & $1 \%$ \\
\hline$\beta$ & $10 \%$ \\
\hline$Z_{1-\alpha}$ & $2.32635^{(\mathrm{a})}$ \\
\hline$Z_{1-\beta}$ & $1.28155^{(\mathrm{b})}$ \\
\hline MARSSIM Overage & $10 \%$ \\
\hline
\end{tabular}

(a) This value is automatically calculated by VSP based upon the user defined value of $\alpha$.

(a) This value is automatically calculated by VSP based upon the user defined value of $\beta$.

The following figure is a performance goal diagram, described in EPA's QA/G-4 guidance (EPA 2000). It shows the probability of concluding the sample area exceeds the Authorized Limits threshold on the vertical axis versus a range of possible true median values on the horizontal axis. This graph contains all of the inputs to the number of samples equation and pictorially represents the calculation.

The red vertical line is shown at the threshold (action limit) on the horizontal axis. The width of the gray shaded area is equal to $\Delta$; the upper horizontal dashed blue line is positioned at 1- $\alpha$ on the vertical axis; the lower horizontal dashed blue line is positioned at $\beta$ on the vertical axis. The vertical green line is positioned at one standard deviation below the threshold. The shape of the red curve corresponds to the estimates of variability. The calculated number of samples results in the curve that passes through the lower bound of $\Delta$ at $\beta$ and the upper bound of $\Delta$ at 1- $\alpha$.

\section{MARSSIM Sign Test}

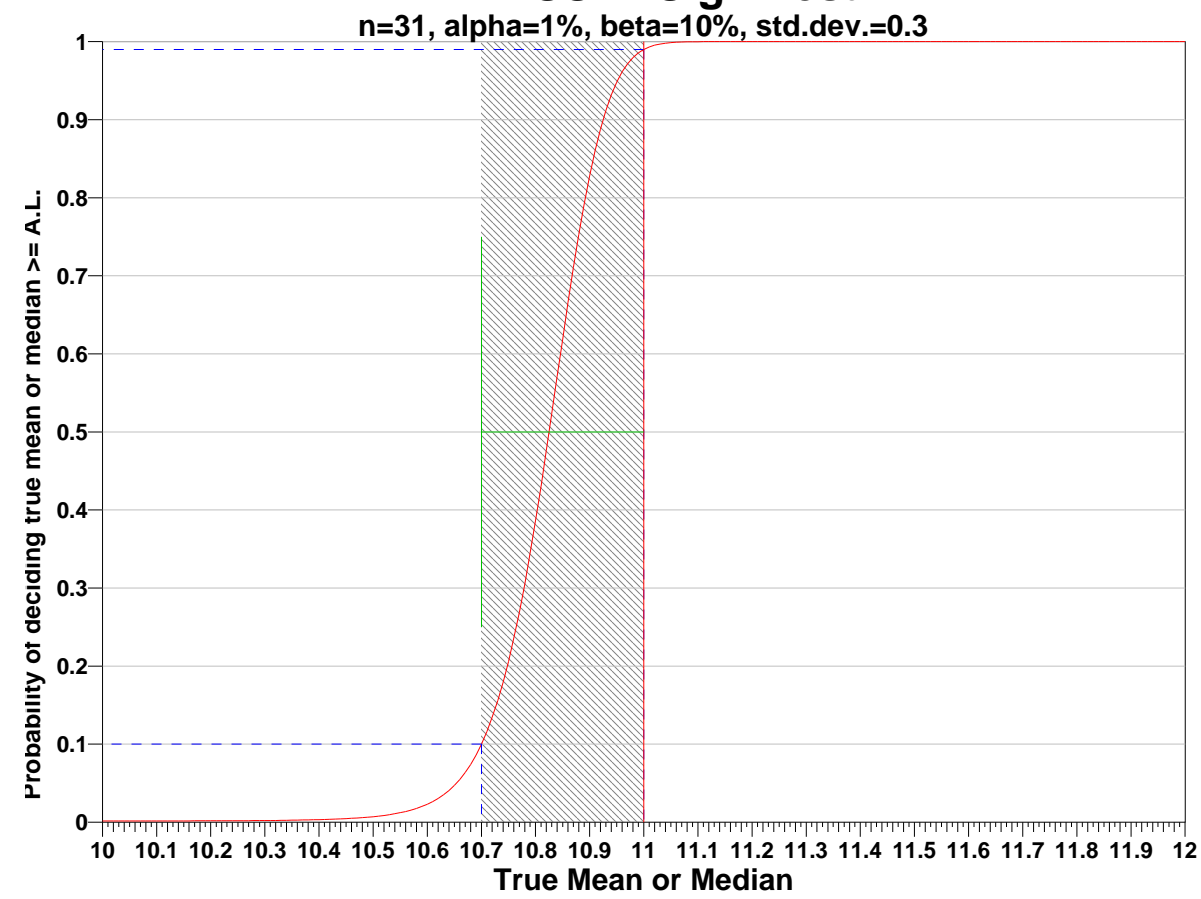




\section{A.5 Statistical Assumptions}

The assumptions associated with the formulas for computing the number of samples are:

1. The computed Sign test statistic is normally distributed,

2. The variance estimate, $S^{2}$, is reasonable and representative of the population being sampled,

3. The population values are not spatially or temporally correlated, and

4. The sampling locations will be selected probabilistically.

The first three assumptions will be assessed in a post data collection analysis. The last assumption is valid because the gridded sample locations were selected based on a random start.

\section{A.6 Recommended Data Analysis Activities}

Post data collection activities will generally follow those outlined in EPA's Guidance for Data Quality Assessment (EPA 2000). The data analysts will become familiar with the context of the problem and goals for data collection and assessment. The data will be verified and validated before being subjected to statistical or other analyses. Graphical and analytical tools will be used to verify to the extent possible the assumptions of any statistical analyses that are performed as well as to achieve a general understanding of the data. The data will be assessed to determine whether they are adequate in both quality and quantity to support the primary objective of sampling.

Because the primary objective for sampling for this site is to compare the site median (mean) value with a threshold value (i.e., Authorized Limits), the data will be assessed in this context. Assuming the data are adequate, at least one statistical test will be done to perform a comparison between the data and the threshold of interest. Results of the exploratory and quantitative assessments of the data will be reported, along with conclusions that may be supported by them. 


\section{Distribution}

No. of

Copies

\section{OFFSITE}

N. Ceto

U.S. Environmental Protection Agency

Region 10

Office of Environmental Cleanup

Director - Hanford Project Office

1200 6th Avenue

Seattle, WA 98101

S. Domotor

EH-41/Forrestal Building

U.S. Department of Energy

1000 Independence Ave., S.W.

Washington, DC 20585

A. Fredin

Confederated Tribes of the Colville

Reservation

P.O. Box 150

Nespelem, WA 99155

R. Gay

Confederated Tribes of the Umatilla Indian

Reservation

P.O. Box 638

Pendleton, OR 97801

P. Golan

EM-2/Forrestal Building

U.S. Department of Energy

1000 Independence Ave., S.W.

Washington, DC 20585

L. Goldstein

Hanford Natural Resources Trustee Council

Washington State Department of Ecology

P.O. Box 47600

Olympia, WA 98504
No. of

Copies

G. Hughes

U.S. Fish and Wildlife Service

3250 Port of Benton Boulevard

Richland, WA 99352-1670

R. Jim, Manager

Environmental Restoration and Waste

Management Program

The Confederated Tribes and Bands of the

Yakama Nation

P.O. Box 151

Toppenish, WA 98948

R. Keck

Energy Northwest

P.O. Box 968

Richland, WA 99352

D. McBaugh

Division of Radiation Protection

Washington State Department of Health

P.O. Box 47890

Olympia, WA 98504-7890

L. Oakes

Energy Northwest

P.O. Box 968

Richland, WA 99352

O. Patt, Jr., Council Chairman

Confederated Tribes of the Warm Springs

Reservation

P.O. Box 1299

Warm Springs, OR 97761

M. Ritter

U.S. Fish and Wildlife Service

3250 Port of Benton Boulevard

Richland, WA 99352 
No. of

\section{Copies}

G. Schreckhise, Associate Dean

Washington State University Tri-Cities

2710 University Drive

Richland, WA 99352

L. Seelatsee

Wanapum People

P.O. Box 878

Ephrata, WA 98823

P. Sobotta, Director

ERWM

Nez Perce Tribe

P.O. Box 365

Lapwai, ID 83540

E. Stensgar, Chairman

Coeur d'Alene Tribal Council

P.O. Box 408

Plummer, ID 83851-9704

\section{A. Wallo}

EH-412/Forrestal Building

U.S. Department of Energy

1000 Independence Ave., S.W.

Washington, DC 20585

J. Watts

Federal Advisory Committee

c/o U.S. Fish and Wildlife Service

3250 Port of Benton Boulevard

Richland, WA 99352
No. of

Copies

\section{ONSITE}

25 DOE Richland Operations Office

B. Bilson A3-04

K. V. Clarke A7-75

J. L. Daily A3-04

P. F. Dunigan, Jr. A5-58

W. M. Glines (5) A6-39

J. B. Hall A2-15

H. B. Hathaway A2-15

K. A. Klein A7-50

A. Larsen A2-15

J. D. Voice A7-75

D. C. Ward (5) A2-15

S. H. Wisness A2-15

J. H. Zeisloft A2-15

DOE Public Reading Room (2) H2-53

Administrative Record (2) H6-08

2 Fluor Hanford, Inc.
A. R. Johnson
H5-26
D. B. Ottley
H5-26

19 Pacific Northwest National Laboratory
E. J. Antonio
K3-54
R. L. Dirkes (5)
K6-75
B. G. Fritz (5)
K6-75
R. H. Hanf
K6-75
B. A. Napier
K3-54
G. P. O’Connor
K6-86
G. W. Patton
K6-75
T. M. Poston
K6-75
Hanford Technical Library (2)
P8-55
LMSI Central Files 